\title{
Evaluating the suitability of diagenetic dolomite as an archive for paleo-seawater chemistry
}

\author{
M.D. NADEAU ${ }^{1 *}$ J.G. MURPhY ${ }^{1}$ J.A. HigGinS ${ }^{1}$ \\ ${ }^{1}$ Princeton University, Depaetment of Geoscinces, Guyot \\ Hall, Princeton, NJ 08544, USA
}

Distinguishing the style and timing of dolomitization is critical to understanding dolomite's suitability as a proxy for reconstructions of Earth's ancient oceans and atmosphere. While sedimentary successions of marine carbonates are ubiquitous in the geological record, the environmental information recorded in the elemental and isotopic compositions reflect a combination of surface and subsurface environments. Primary carbonate minerals undergo diagenetic alteration, the most widespread and enigmatic of these diagenetic processes is dolomitization; the conversion of calcium carbonate $\left(\mathrm{CaCO}_{3}\right)$ to calcium-magnesium carbonate $\left(\mathrm{Ca} 0.5 \mathrm{Mg}_{0.5} \mathrm{CO}_{3}\right)$. We use carbonate $\delta^{44 / 40} \mathrm{Ca}$ and $\delta^{26} \mathrm{Mg}$ values to evaluate the suitability of diagenetic dolomites as an archive for paleo-seawater chemistry recorded in Resolution Guyot, a 1691-meter thick succession recording shallowwater carbonates deposited and dolomitized in the Early Cretaceous. A second episode of dolomitization, dated using measurements of ${ }^{87} \mathrm{Sr} /{ }^{86} \mathrm{Sr}$ ratios [1], occurred during the Oligocene. As the burial history of Resolution Guyot is uncomplicated, seawater is the only potential diagenetic fluid. Using this sample suite, we test the hypothesis for two episodes of dolomitization by Cretaceous and Oligocene seawater. Results are compared to independent geological archives of $\delta^{44 / 40} \mathrm{Ca}$ and $\delta^{26} \mathrm{Mg}$ values. The aim of this work is to test the utility of paired isotopic measurements as a tool for evaluating dolomite's suitability as a proxy in reconstructions of Earth's ancient oceans and atmosphere.

[1] Flood, P. G., \& Chivas, A. R. (1995), Proceedings of the Ocean Drilling Program, Vol. 142, pp. 161-169. 